\title{
A New Species of Simulium (Diptera: Simuliidae) from Open Areas in Central Amazonia, Brazil
}

\author{
Neusa Hamada ${ }^{+}$, Peter H Adler* \\ Coordenação de Pesquisas em Entomologia, Instituto Nacional de Pesquisas da Amazônia, Caixa Postal 478, \\ 69011-970 Manaus, AM, Brasil *Department of Entomology, Clemson University, Clemson, South Carolina \\ 29634, U.S.A.
}

The larva, pupa, male and female of Simulium daltanhani $n$. sp. are described and illustrated. This species shares diagnostic characteristics with Simulium quadrifidum Lutz, Simulium cauchense Floch \& Abonnenc, Simulium brevifurcatum Lutz and Simulium siolii Py-Daniel. It was collected in three counties (Manaus, Presidente Figueiredo and Itacoatiara) in the State of Amazonas, Brazil. Its habitat includes streams in disturbed, open areas where the forest has been cut for road construction; it was not collected in adjacent forested streams, suggesting that it colonizes disturbed habitats. The larval subesophageal ganglion is discussed as a useful character, when pigmented, to distinguish this species within a limited geographic area.

Key words: Amazon - aquatic insects - black fly - Simuliidae - Simulium

The subgenus Psaroniocompsa Enderlein, 1934, as treated by Crosskey and Howard (1997), contains five species-groups, two of which (Simulium amazonicum and S. quadrifidum SpeciesGroups) were considered valid subgenera (Cerqueirellum and Coscaroniellum, respectively) by South American workers such as Py-Daniel (1983), Coscarón (1987), and Coscarón et al. (1992). Py-Daniel and Sampaio (1994) regarded these taxa as genera.

In the present paper, we describe the larva, pupa, male and female of a new species of Simulium, and discuss the value of the larval subesophageal ganglion as a taxonomic character for species in Central Amazonia. We do not assign this new species to a particular subgenus or species-group because it shares diagnostic characteristics with species related to Simulium quadrifidum Lutz (S. quadrifidum Species-Group $=$ Coscaroniellum), Simulium siolii Py-Daniel and Simulium brevifurcatum Lutz ( $S$. siolii and $S$. auristriatum Species-Groups, respectively = Psaroniocompsa in part).

\footnotetext{
This is Technical Contribution No. 4341 of the South Carolina Agricultural Experiment Station, Clemson University.

${ }^{+}$Fellowship from CNPq (201165/93-7) and corresponding autor. Fax: +55-92-236.3822

Received 11 September 1997

Accepted 8 January 1998
}

\section{MATERIALS AND METHODS}

Larvae and pupae were collected from 10 streams in Manaus, Itacoatiara and Presidente Figueiredo counties, in the State of Amazonas, Brazil, in 1995 and 1996, and fixed in Carnoy's solution (1 part glacial acetic acid: 3 parts absolute ethanol). Some pupae were reared to adults.

Nomenclature follows that used by Adler (1987), Coscarón (1987) and Py-Daniel (1981). The following specimens of $S$. brevifurcatum, for comparison, were loaned by the Museu de Zoologia, Universidade de São Paulo (MZUSP): three males and pupal exuviae numbered by Vulcano 138-129, 80-171 and 148-16; and four slides numbered 98-10 (female parts), 98-10 (female pupal exuviae), 98116 (male parts) and 98116 (male pupal exuviae).

The holotype and some paratypes are deposited in the Instituto Nacional de Pesquisas da Amazônia (INPA), Manaus; other paratypes are deposited in the MZUSP, São Paulo, SP, Brazil; in the Clemson University Arthropod Collection (CUAC), Clemson University, S.C., U.S.A, and in the National Museum of Natural History (NMNH), Washington, D.C., U.S.A. Voucher specimens of other species examined are deposited in INPA.

\section{DESCRIPTION}

\section{Simulium daltanhani New Species \\ Hamada \& Adler \\ Figs 1-35}

Simulium "C" Hamada, 1997.

Simulium sp. Hamada, Costa \& Magni-Darwich, 1997. 

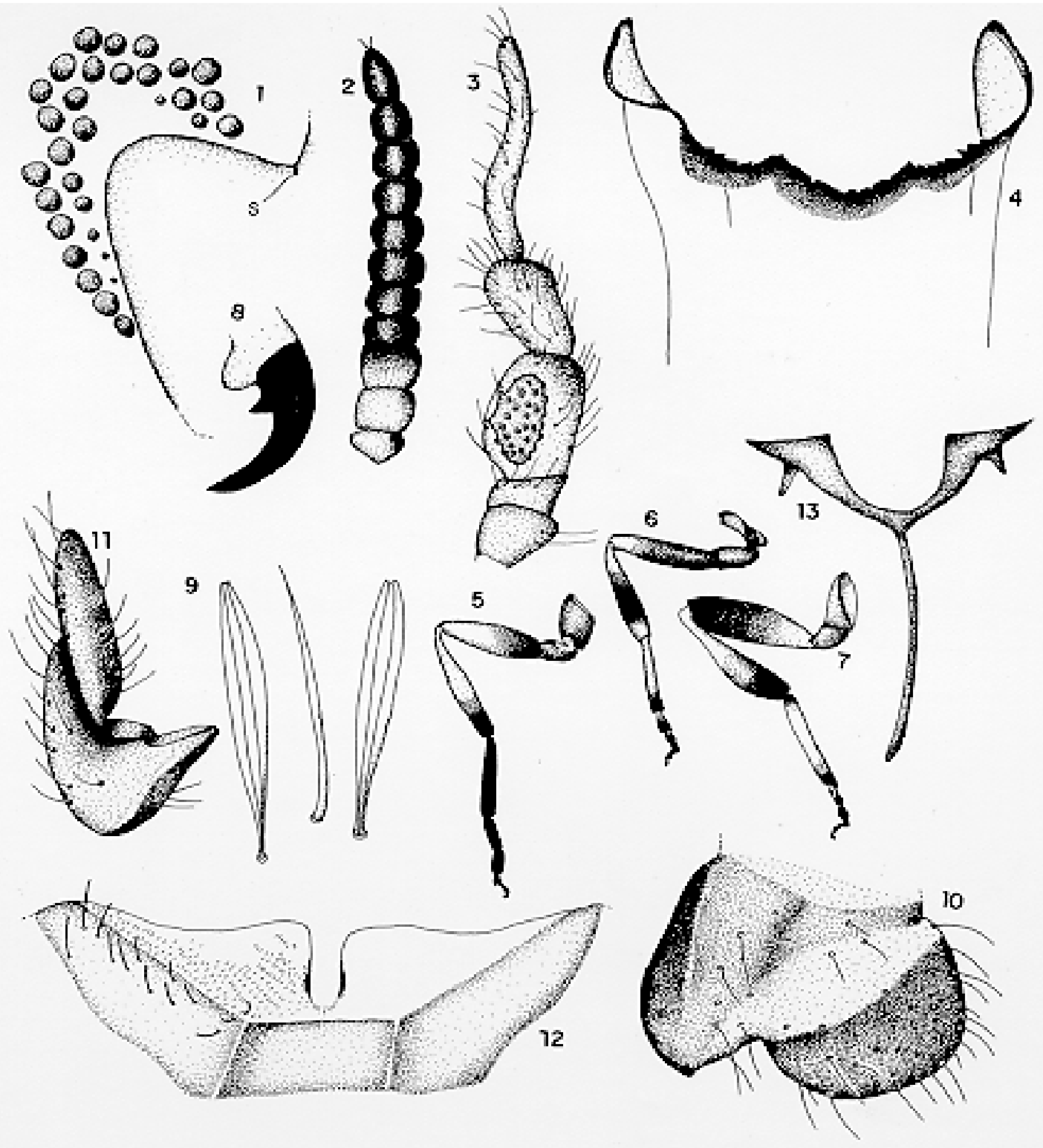

Simulium daltanhani n. sp., female. Fig. 1: fronto-ocular triangle, s=frontal suture. Fig. 2: antenna. Fig. 3: maxillary palpus. Fig. 4: cibarium. Fig. 5: fore leg. Fig. 6: middle leg. Fig. 7: hind leg. Fig. 8: tarsal claw. Fig. 9: filiform and scale-like setae from legs. Anal lobe and cercus. Fig. 10: lateral view. Fig. 11: ventral view. Fig. 12: hypogynial lobe (ventral view); setae and microtrichia omitted on right side. Fig. 13: genital fork.

Female - General body color black; body length $1.9-2.4 \mathrm{~mm}(\overline{\mathrm{x}}=2.1 \mathrm{~mm}, \mathrm{n}=12)$; thoracic length 0.9-1.0 $\mathrm{mm}(\overline{\mathrm{x}}=1.0 \mathrm{~mm}, \mathrm{n}=5)$. Wing length 2.0 $\mathrm{mm}(\mathrm{n}=5)$, width $1.0-1.1 \mathrm{~mm}(\overline{\mathrm{x}}=1.1 \mathrm{~mm}, \mathrm{n}=5)$.

Frons, clypeus and occiput with silvery blue pruinosity; frons longer than wide; fronto-ocular suture small (Fig. 1); fronto-ocular triangle as in Fig. 1. Antenna $(0.5-0.6 \mathrm{~mm})$ with silver pubescence; each with pedicel, scape and first flagellomere brownish yellow; following flagellomeres dark brown (Fig. 2). Palpi dark brown; each with sensory vesicle elongate, wide, occupying more than $50 \%$ of palpomere III, and with short neck (Fig. 3); palpomere V 1.8 times as long as palpomere III and 2.0 times as long as palpomere IV. Mandibles each with 9 external serrations and 24 internal teeth. Laciniae each with 20-22 retrorse teeth. Cibarium with serrations and 
round teeth; medial region heavily sclerotized (Fig. 4). Pharynx with cluster of sharp teeth proximally. Scutum black, with thin, reddish gold hairs, not distributed in line; 2 thin, rectangular, silver spots on anterolateral margin, connected with silver band around lateral and posterior margins of scutum; 4 short, submedian, pruinose bands faintly visible, best seen with anterior lighting if hair is rubbed off thorax. Anepisterna and katepisterna dark brown, with silver pruinosity. Scutellum black, with long, black hairs; postnotum black, with silver pruinosity. Wing veins yellowish brown; setae and spines brown; Sc and base of R bare. Halters each with basal region dark brown and terminal region yellow. Front legs (Fig. 5) each with coxa, trochanter and femur proximal to medial region brown; distal region of tibia and all tarsomeres black. Middle legs (Fig. 6) each with coxa, trochanter and most of femur brown; tibia with medial region dark; basitarsus dark brown distally. Hind legs (Fig. 7) each with coxa and trochanter light brown; femur dark distally, paler proximally; tibia dark on distal 1/3; basitarsus with dark patches on proximal and distal ends; following tarsomeres dark; calcipala as broad as long, reaching pedisulcus. Tarsal claws each with basal tooth (Fig. 8). Femora and tibiae with scale-like and filiform setae (Fig. 9). Abdominal sclerites dark brown, with long, black setae on terminal tergites; membranous areas gray to brown. Basal fringes of thin, long, black hairs, highlighted with gold. Tergite II with silver pruinosity; tergites VI-VIII with varnish-like appearance. In lateral view, cerci rounded, anal lobes subtriangular (Fig. 10); in ventral view as in Fig. 11; hypogynial lobes (Fig. 12) subtriangular, with abundant microtrichia. Genital fork (Fig. 13) with stem moderately long, slender; lateral arms forming suboval space in region of bifurcation. Spermatheca subspherical, with cuticular microspines; spermathecal duct and area of attachment unpigmented.

Male - General body color black; body length 2.1$2.6 \mathrm{~mm}(\overline{\mathrm{x}}=2.4 \mathrm{~mm}, \mathrm{n}=10)$; thoracic length 0.8-0.9 $\mathrm{mm}(\overline{\mathrm{x}}=0.8 \mathrm{~mm}, \mathrm{n}=5)$. Wing length $1.9 \mathrm{~mm}(\mathrm{n}=5)$, width $1.0 \mathrm{~mm}(\mathrm{n}=5)$.

Frons, clypeus and occiput with silvery blue pruinosity. Antennae each $0.50 \mathrm{~mm}$ in length; pedicel and scape brownish yellow; flagellum (Fig. 14) dark brown. Palpi (Fig. 15) dark brown; each with palpomere $\mathrm{V}$ about 1.8 times as long as palpomere III and 1.7 times as long as palpomere IV; sensory vesicle small, subspherical. Scutum black, with reddish gold hairs not distributed in line; 2 thin, rectangular silver spots on anterolateral margin, connected with silver band around lateral and posterior margin of scutum; 1 pair of thin, silver submedian bands faintly visible with anterior lighting. Scutellum black; postnotum black, with silver pruinosity. Anepisterna and katepisterna dark brown. Wing veins yellowish brown; spines and setae brown; Sc and base of R bare. Halters and legs with same color pattern as female. Abdominal tergites black; basal fringes of thin, long, black hairs and golden highlights; tergite II with silver pruinosity; tergites V-VIII with silver pruinosity forming band laterally. Gonocoxites and gonostyli black, with silver pubescence; gonocoxites (Figs 16, 17) each as long as wide; gonostyli (Figs 16-19) each 0.5 times as long as gonocoxite, longer than wide, bearing 1-2 teeth apically, and 1 thin spine on lateral flange. Ventral plate (Fig. 20), in ventral view, subrectangular. Median sclerite (Fig. 21) sub-oval with small, medial concavity. Parameres (Fig. 22) with numerous spines.

Pupa (Figs 23, 24) - Length 1.7-2.3 mm (0=2.0 $\mathrm{mm}, \mathrm{n}=7$ ). Cocoon light brown, slipper-shaped, with median anterodorsal projection; individual threads distinct; anterior margin slightly reinforced lateral to median projection; length along dorsal surface 3.0-3.4 mm; ventral surface 2.7-3.4 mm. Head projected downward, with 3 pairs of bifid trichomes; tubercles dome-shaped (Figs 25, 26); gills each $3.9-4.0 \mathrm{~mm}$ long, with 6 anteriorly directed, slender filaments, not in same plane; 3 short primary petioles, each giving rise to 2 divergent filaments. Thorax with dome-shaped tubercles, 10 bifid trichomes, and 2 simple lateral trichomes. Abdominal chaetotaxy as in Fig. 27 (one side only): tergite I with 2 long setae; tergite II with 8 setae; tergites III and IV each with 4 anteriorly directed hooks on posterior margin, plus 2-4 small setae; tergite $\mathrm{V}$ with 4 submedian setae, 1 small lateral seta, 1 anterior seta, and small groups of comblike spines on anterolateral margin; tergites VI-IX each with anterior comb-like, fine, posteriorly directed spines; tergite VI with 3 setae; tergite VII with 2 submedian setae; tergite VIII with 2 setae on posterior margin; tergite IX with 1 small seta and 1 short, slightly curved terminal spine. Pleural membrane usually with 2-3 small setae per segment. Sternites III-VIII each with anterior medial group of microspines; sternites IV and V each with 1-2 lateral setae and 1-2 stout hooks (simple-quadruple). Sternites VI and VII each with 2 plates (1 small plate laterally and 1 larger plate submedially); each small plate bearing 1 simple hook, and each larger plate with 1-2 hook (bifid-trifid) and 1-2 sublateral setae.

Larva (final instar) (Fig. 28) - Length 4.8-5.5 mm $(\overline{\mathrm{x}}=5.2 \mathrm{~mm}, \mathrm{n}=32)$; head capsule lateral length 0.4 $\mathrm{mm}(\mathrm{n}=3)$, dorsal width $0.50 \mathrm{~mm}(\mathrm{n}=3)$. General coloration brownish green (in Carnoy's solution). Head capsule (in dorsal view) (Fig. 29) with dark 


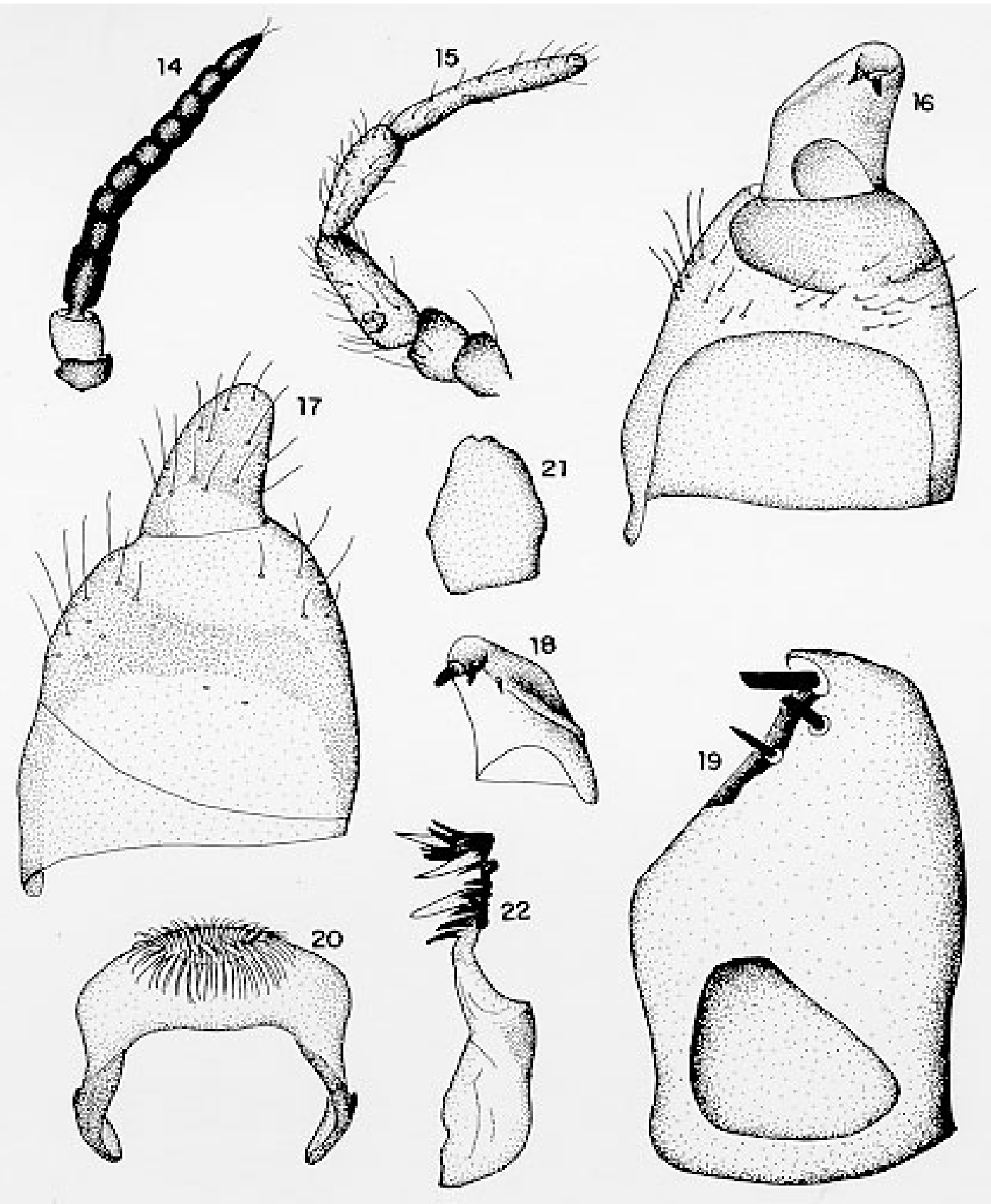

Simulium daltanhani n. sp., male. Fig. 14: antenna. Fig. 15: maxillary palpus. Gonocoxite and gonostylus. Fig. 16: dorsal view. Fig. 17: ventral view. Fig. 18 ventrolateral view. Fig. 19: dorsal view. Fig. 20: ventral plate (ventral view). Fig. 21: median sclerite. Fig. 22: paramere.

region on midline and along basal margin, with small simple setae. Cervical sclerites small, elliptical, free in membrane. Postgenal cleft (Fig. 30) longer than wide, widest at midpoint, tapered apically; postgenal bridge $0.5-0.8$ times as long as hypostoma. Subesophageal ganglion heavily pig- mented (Fig. 30). Antennae (Fig. 31) subequal in length to labral-fan stalks; each with distal article longer than medial and proximal articles; medial article shorter than proximal one; proportions of articles (proximal to distal, excluding apical sensillum) 1.0:0.7-0.9:1.2-1.5. Labral fans each with 

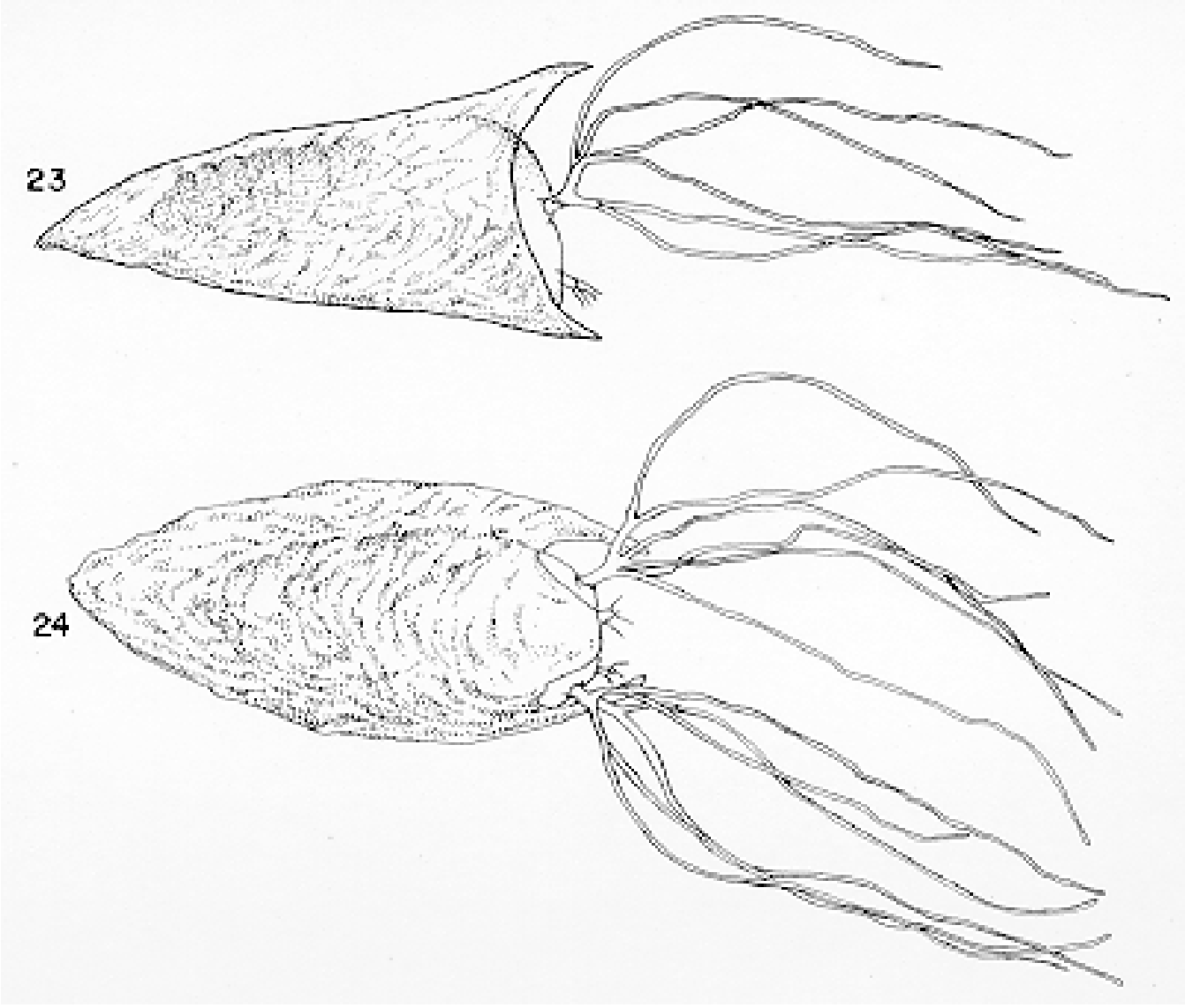

Simulium daltanhani n.sp., pupa. Fig. 23: lateral view. Fig. 24: dorsal view.

49-51 primary rays. Hypostoma (Fig. 32) with median tooth smaller than lateral teeth; sublateral teeth small; lateral margin of hypostoma with 2 paralateral teeth and 3-6 lateral serrations per side; hypostoma with 4 setae per side. Lateral mandibular processes each scale-like, not bifurcated (Fig. 33 ), reaching inferior margin of mandible; mandibular teeth: 1 apical, 2 external, 3 subapical (third subequal to second and both smaller than first), and 8-9 internal teeth; 1 large mandibular serration and 1 small mandibular sensillum (sensu Craig \& Craig 1986). Labral sclerite as in Fig. 34. Body with simple and branched setae; intersegmental bands unpigmented, distinct; ventral tubercles pointed. Gill histoblasts in situ (Fig. 28) large, each with 6 filaments. Anterodorsal arms of anal sclerite (Fig. 35) thinner and shorter in length than posteroventral arms, associated with thin, simple (few branched) setae. Posterior proleg bearing 6066 rows of 12-13 hooks each. Anal papillae consisting of 3 cluster with 9-10 lobules each.

Types. Holotype - male (pinned) with pupal exu- viae (in glycerin microvial), $\mathrm{km} 8$ on small road off AM010 Highway at $\mathrm{km} \mathrm{51,} \mathrm{preserved} \mathrm{area} \mathrm{of}$ Brazilian Army (Centro de Instrução de Guerra na Selva, CIGS), Manaus county, $02^{\circ} 45^{\prime}$ 'S 59 $51^{\prime}$ 'W, coll. N Hamada, 29/VI/96 (INPA). Paratypes - same locality as holotype, coll. N Hamada, 20/VII/95 (3 pupae - INPA); same locality as holotype, coll. N Hamada, 29/VI/96 (5 $\overbrace{}^{\star}, 5$ +, 10 larvae, 10 pupae INPA; $5 \sigma^{\circ}, 5$ , 10 larvae, 10 pupae - MZUSP; 17 larvae, 5 pupae - CUAC); 18/III/96 (1 pupa INPA), 29/VI/96 (10 larvae, 10 pupae - MZUSP); road to cemetery, Presidente Figueiredo county, $02^{\circ} 02^{\prime}$ 'S $60^{\circ} 39^{\prime} \mathrm{W}$, coll. N Hamada \& FF Xavier Filho, 25/III/96 (1 larva - INPA); near entrance to Sabiá I, Reserva Ducke, Manaus county, $03^{\circ} 00^{\prime} \mathrm{S}$ $59^{\circ} 56^{\prime} \mathrm{W}$, coll. N Hamada, 12/VII/95 (2 $0^{\star}, 2$ \% , 1 pupa - CUAC; $10^{7}, 1$ ㅇ - NMNH), 19/VII/95 (5 larvae, 11 pupae - INPA); near Sítio Lobato, rua Península, between Vivenda Verde and Vivenda do Portal, Manaus county, $02^{\circ} 58^{\prime}$ 'S 60 $60^{\circ} 04^{\prime} \mathrm{W}$, coll. N Hamada, 2/V/96 (4 larvae, 1 pupa - INPA); first stream before Igarapé Água Branca, on Água 


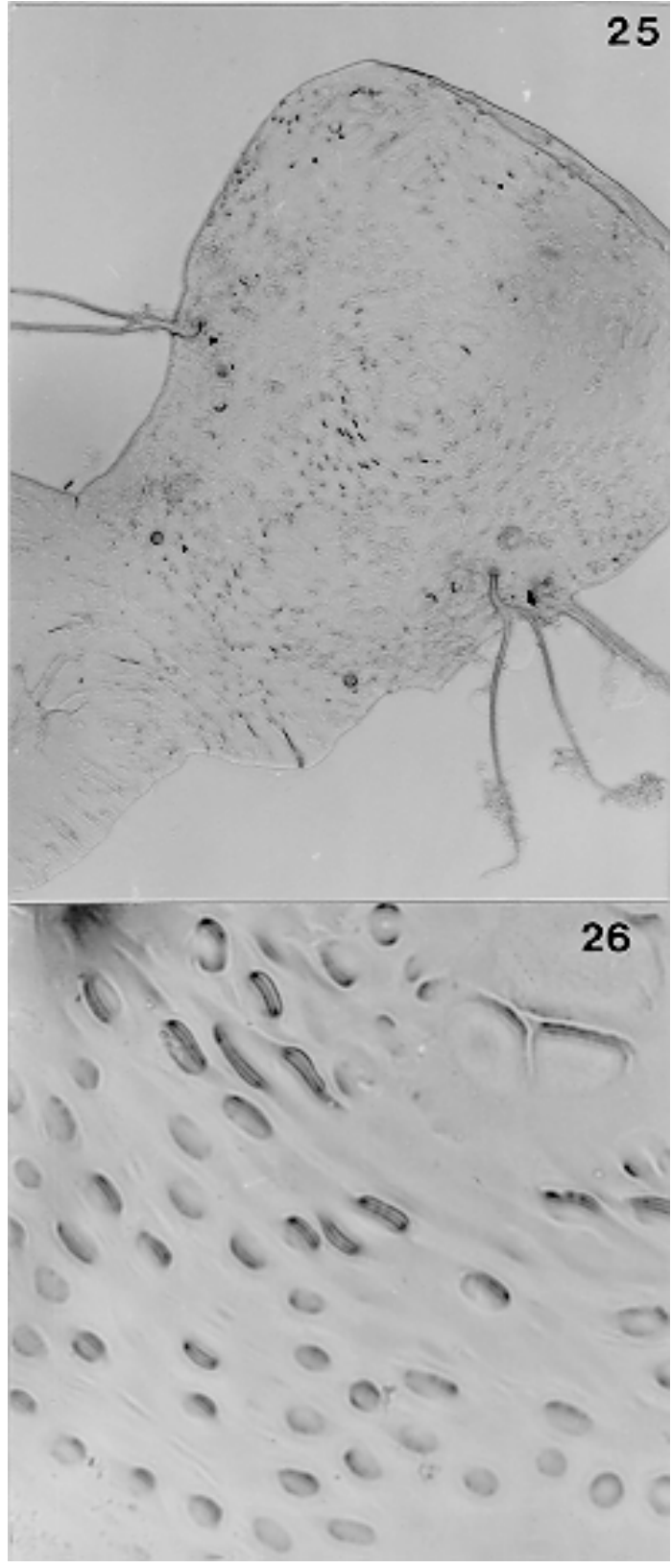

Simulium daltanhani n.sp., pupa. Fig. 25: cephalic plate. Fig. 26: dome-shaped tubercles of cephalic plate.

Branca I road, AM010 Highway km 30, Manaus county, 02 $49^{\circ}$ 'S 59 $58^{\circ} \mathrm{W}$, coll. N Hamada \& FF Xavier Filho, 9/V/96 (4 larvae, 4 pupae - INPA); second stream before Igarapé Água Branca, on Água Branca I road off AM010 highway at km 30, Manaus county, $02^{\circ} 49^{\prime}$ 'S 59 $58^{\circ} \mathrm{W}$, coll. N Hamada \& FF Xavier Filho, 9/V/96 (2 larvae - INPA); fourth stream before Água Branca I road, AM010 km 30, Manaus county, $02^{\circ} 49^{\prime} \mathrm{S} 59^{\circ} 58^{\prime} \mathrm{W}$, coll. N Hamada \& FF Xavier Filho, 17/V/96 (1 larva - INPA); sixth stream before Água Branca I road, AM010 Highway $\mathrm{km} \mathrm{30}$, Manaus county, 02 $49^{\circ} \mathrm{S} 59^{\circ} 58^{\prime} \mathrm{W}$, coll. N Hamada \& FF Xavier Filho, 17/V/96 (1 larva, 1 pupa - INPA); road to Itapiranga, Madeireira Mil área, Itacoatiara county, $03^{\circ} 05^{\prime} \mathrm{S}$ $59^{\circ} 60^{\prime} \mathrm{W}$, coll. N Hamada \& L Aquino, 28/V/96 (2 larvae, 1 pupa - INPA); Nova Vida road off AM010 Highway near Aruanã Farm, Itacoatiara

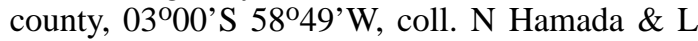
Aquino, 28/V/96 (7 larvae, 10 pupae - INPA). Etymology - This species is named in honor of Professor Daltanhan da Silva Reis (UNESP/São José do Rio Preto, SP), who opened the insect world to the first author.

Diagnosis - The larva of S. daltanhani can be distinguished from larvae of other species in the known range by the presence of a heavily pigmented subesophageal ganglion (Fig. 30). Because this character can be seen even in the earliest instars, it allows larvae of the new species to be separated from those for which the ganglion is not heavily pigmented. Coscarón et al. (1992) did not discuss the pigmentation of this ganglion in larvae of $S$. cerradense; however, larvae of S. cerradense can be distinguished by the presence of lateral mandibular processes that are bifid, whereas in the new species the processes are scale-like (Fig. 33), not bifurcated.

$S$. brevifurcatum is similar to the new species in the pupal stage, having the same number and similar arrangement of gill filaments, dome-shaped tubercles on the head and thorax (although they are much smaller), and a cocoon with an anteromedian projection. However, according to the description of Py-Daniel et al. (1985), its larva can be distinguished from that of the new species by the shape of the postgenal cleft and by the antennal color pattern. In the adult stage, $S$. brevifurcatum can be distinguished from the new species by the presence of grouped golden hairs on the scutum, in S. brevifurcatum forming patches rather than unevenly distributed hairs; by the color pattern of the middle leg (without dark patches on the tibia and femur in S. brevifurcatum); by the wider scale-like setae on the femora and tibiae; and by the configuration of the female cibarium. Although the pupa of $S$. cerradense has six filaments branching near the base (Coscarón et al. 1992), as in the new species, it can be distinguished by the presence of acute tubercles on the head and thorax, absence of an anteromedian projection on the cocoon and the "gelatinous" nature of the cocoon in S. cerradense.

The females of $S$. quadrifidum, S. cauchense and $S$. cerradense can be distinguished from the female of the new species by the presence of paired median silver bands of variable length. The fe- 


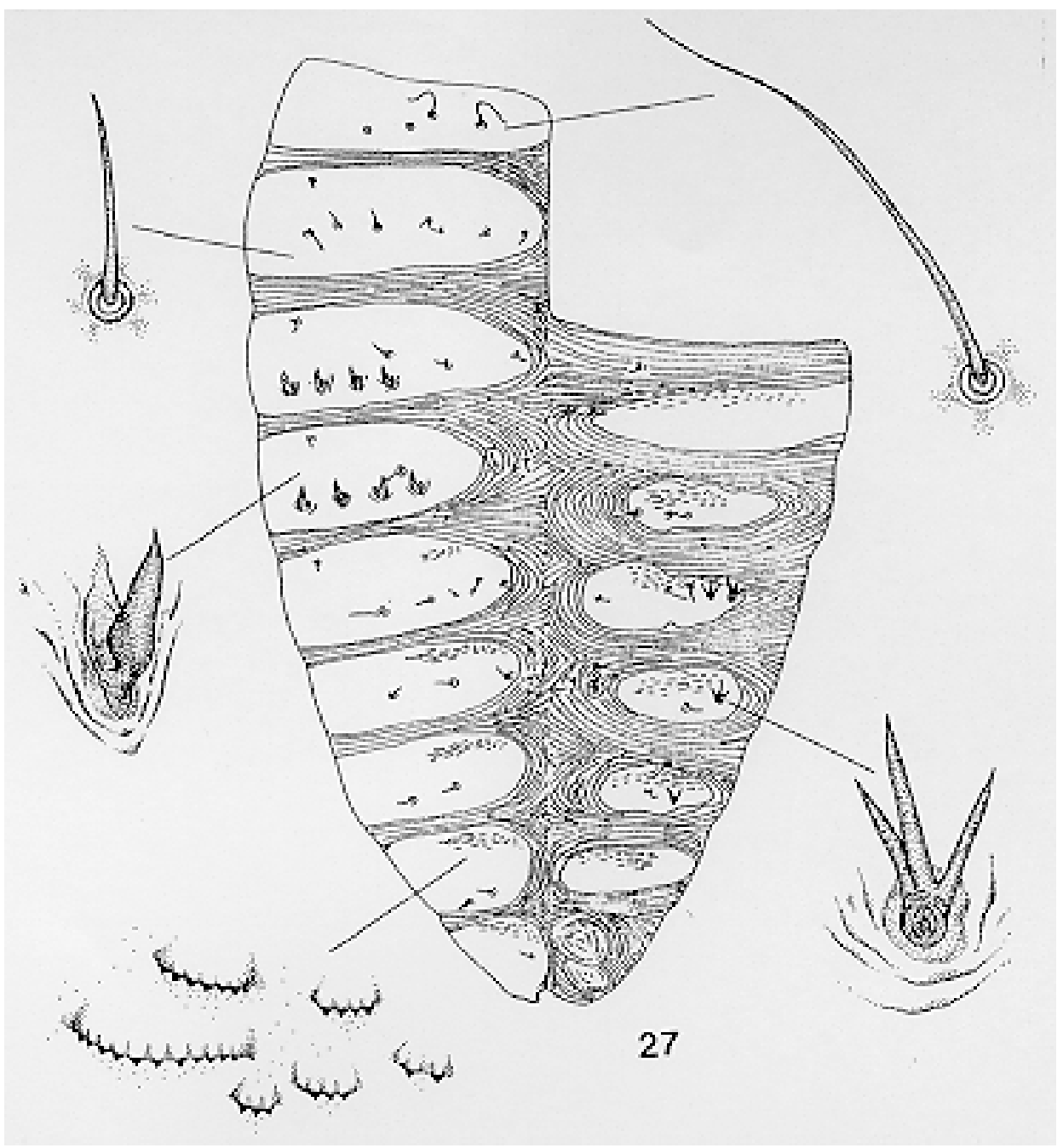

Fig. 27: Simulium daltanhani n.sp., pupa. Abdomen: dorsal view (left side), ventral view (right side).

male of Simulium goeldii Cerqueira \& Nunes de Mello does not have these median silver bands; however, it can be distinguished from that of the new species by its smaller size, by the much smaller palpal sensory vesicles and by the configuration of the cibarium. The male of $S$. daltanhani has gonostyli each with one or two apical teeth and a smaller spine (sometimes difficult to see) located laterally on a flange (Figs 18, 19); the gonostylus distinguishes the male of the new species from males of all other known species in Central Amazônia. The male of S. siolii, which occurs in the states of Mato Grosso and Rondônia, also has gonostyli each with one large apical tooth and one small lateral tooth (Py-Daniel 1988), but other characters in the adult, pupa and larva distinguish the two species.

\section{REMARKS}

When the larval subesophageal ganglion is pigmented, as in S. daltanhani, it can be useful for distinguishing species within a limited area because it is not common in this configuration and can be seen in specimens fixed in ethanol or Carnoy's solution. For example, for the species in the State of Roraima and in the Grand Savanna region of Venezuela, the ganglion is pigmented in Simulium incrustatum Lutz, Simulium exiguum Roubaud, and Simulium spinibranchium Lutz. S. spinibranchium and Simulium kabanayense Ramírez Pérez \& Vulcano occur together in some streams of the Grand Savanna, and are difficult to distinguish if larvae are not late instars; however, the unpigmented ganglion of $S$. kabanayense permits its identification. Although 


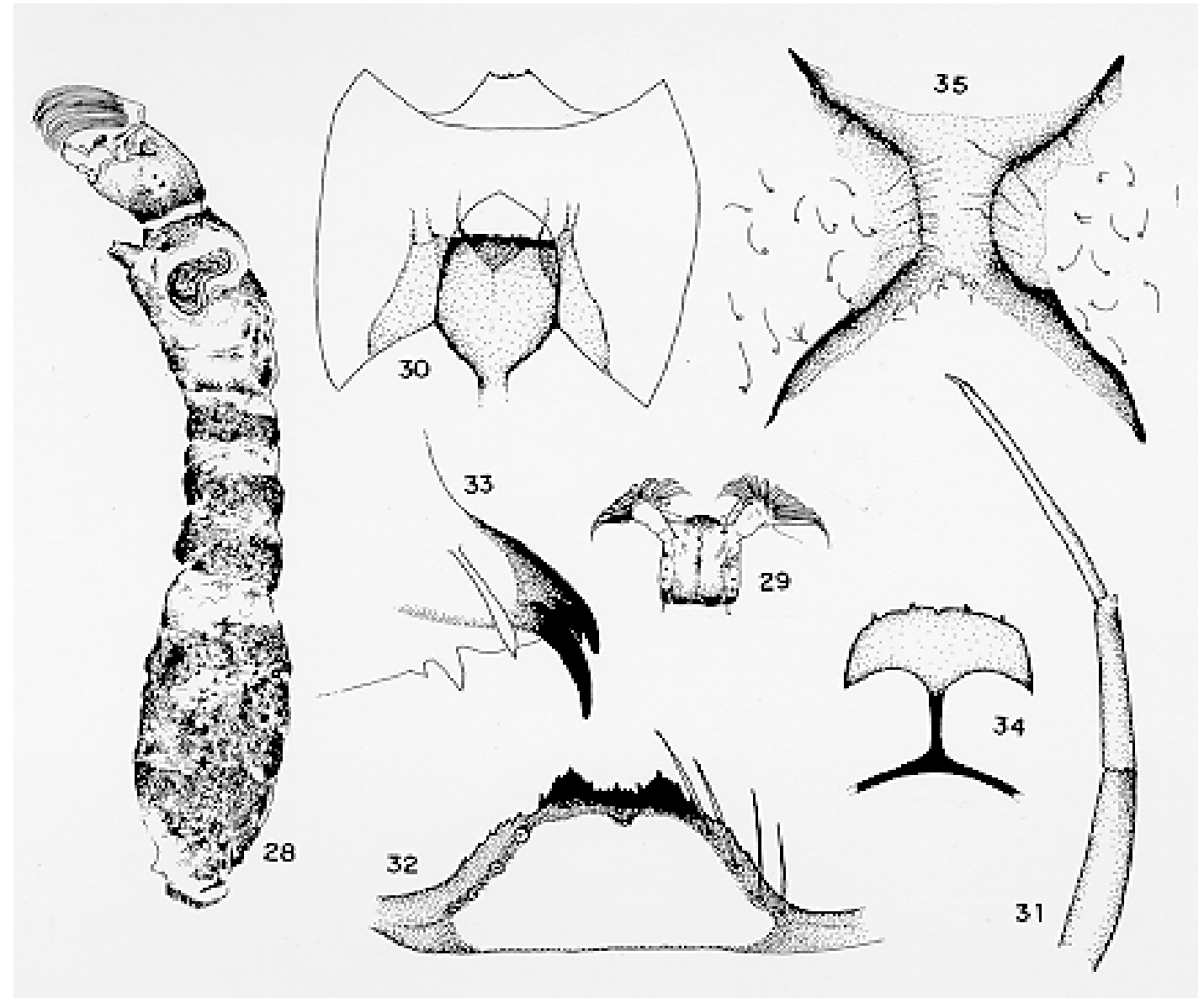

Simulium daltanhani n. sp., larva. Fig. 28: larval habitus (lateral view). Fig. 29: head (dorsal view). Fig. 30: subesophageal ganglion. Fig. 31: antenna. Fig. 32: hypostoma. Fig. 33: apex of mandible, showing lateral mandibular process. Fig. 34: labral sclerite. Fig. 35: anal sclerite.

S. incrustatum larvae are polymorphic in body color, varying from dark green with bands to almost white without bands, the pigmented subesophageal ganglion still can be seen in all larvae. More observations are needed to determine if the shape of the ganglion can distinguish those species for which this structure is pigmented. Adler and Kuusela (1994) used the pigmentation of this ganglion as one of the characters to distinguish three sibling species in the $S$. tuberosum complex in northern Finland.

\section{BIOLOGY}

Larvae and pupae were collected from small, sandy, shallow streams (depth, $x=12.4 \mathrm{~cm}$; width, $\mathrm{x}=1.0 \mathrm{~m}$; discharge, $\mathrm{x}=0.03 \mathrm{~m}^{3} \mathrm{~s}^{-1}$; water temperature, $26-29^{\circ} \mathrm{C} ; \mathrm{pH}, 4.5-5.2$; conductivity, $0-10$ $\mathrm{mScm}^{-1} ; \mathrm{n}=10$ ), sometimes in places where only a thin film of water dripped over the substrate. In the above-mentioned situation, most of the pupal gill filaments were broken near the bifurcation region; larvae were found on undersurfaces of the substrate. Larvae and pupae attached themselves to fallen leaves, trailing grasses and plant stems (Hamada et al. 1997).

The new species was collected nine times with Simulium perflavum Roubaud, twice with $S$. quadrifidum and twice with $S$. goeldii; in one stream, $S$. daltanhani was collected alone. These results show that this species occupies habitats similar to those of $S$. perflavum (Hamada 1997). Because $S$. daltanhani was not collected from streams in the nearby forested areas, it probably colonizes disturbed habitats, as does $S$. perflavum, which is spreading to streams located in habitats altered by human development (Hamada 1997). 
We have no information on the female feeding habits of this new species. However, we did not encounter anthropophilic black flies at any of the ten sites where we collected immatures of this new species, suggesting that $S$. daltanhani may not be anthropophilic.

\section{ACKNOWLEDGMENTS}

To the Brazilian Army (CIGS) for granting permission to work on their reserve in Manaus county; to Francisca do Val (MZUSP) for lending specimens of $S$. brevifurcatum; to Artêmio C da Silva (larval and pupal habitus) and Alexandre L Kirovsky (pupal abdomen) for some of the drawings; to JA Rafael and PM Fearnside for reviewing the manuscript.

\section{REFERENCES}

Adler PH 1987. A new North American species in the Simulium vernum group (Diptera: Simuliidae) and analysis of its polytene chromosomes. Proc Entomol Soc Wash 89: 673-681.

Adler PH, Kuusela K 1994. Cytological identities of Simulium tuberosum and S. vulgare (Diptera: Simuliidae), with notes on other Palearctic members of the S. tuberosum species-group. Entomol Scand 25: 439-446.

Coscarón S 1987. El Género Simulium Latreille en la Región Neotropical: Análisis de los Grupos Supraespecíficos, Especies que los Integran y Distribución Geográfica (Simuliidae, Diptera), Museu Paraense Emílio Goeldii, Coleção Emilie Snethlage, MCT - CNPq, 111 pp.

Coscarón S, Cerqueira RL, Schumaker TTS, La Salvia Filho V 1992. Nuevos datos sobre distribución de Simulideos de Brasil y descripción de Simulium (Coscaroniellum) cerradense sp. n. (Diptera, Simuliidae). Revta Bras Entomol 36: 111-119.

Craig DA, Craig EG 1986. Simuliidae (Diptera:
Culicomorpha) of Rarotonga, Cook Islands, South Pacific. New Zealand J Zool 13: 357-366.

Crosskey RW, Howard TM 1997. A New Taxonomic and Geographical Inventory of World Blackflies (Diptera: Simuliidae), The Natural History Museum, London, $144 \mathrm{pp}$.

Hamada N 1997. Cytotaxonomy and Ecology of Four Species in the Simulium perflavum Group (Diptera: Simuliidae) and Associated Black Flies in Central Amazonia, Brazil, Ph.D. Thesis, Clemson University, Clemson, xvii +222 pp.

Hamada N, Costa WLS, Magni-Darwich S 1997. Notes on artificial substrates for black fly (Diptera: Simuliidae) larvae and microsporidian infection in Central Amazonas, Brazil. An Soc Entomol Brasil 26 (in press).

Py-Daniel V 1981. Algumas considerações sobre Simuliidae (Diptera, Nematocera) - II. Acta Amazonica 11: 171-181.

Py-Daniel V 1983. Caracterização de dois novos subgêneros em Simuliidae (Diptera: Culicomorpha) Neotropical. Amazoniana 8: 159-223.

Py-Daniel V 1988. Simuliidae (Diptera: Culicomorpha) no Brasil. VI. Sobre Simulium (Psaroniocompsa) siolii sp.n., Simulium (P.) lourencoi sp.n., e Simulium (P.) damascenoi sp.n. Rev Saúde Públ 22: 292-310.

Py-Daniel V, Sampaio RTM 1994. Jalacingomyia gen.n. (Culicomorpha): a ressurreição de Gymnopaidinae; a eliminação do nível tribal; apresentação de novos caractéres e a redescrição dos estágios larval e pupal de Simulium colombaschense (Fabricius, 1787) (Diptera: Simuliidae). Mem CAICET IV: 101-148.

Py-Daniel V, Konrad HG, Gastal HAO 1985. Simuliidae (Diptera, Culicomorpha) no Brasil. IV. Descrição das larvas de Simulium (Psaroniocompsa) brevifurcatum Lutz, 1910; S. (P.) anamariae Vulcano, 1962; S. (Thyrsopelma) itaunense D'Andretta \& Dolores Gonzales, 1962. Iheringia. Série Zoologia: 95-102. 
